\title{
Evaluation of the results of patients who underwent coronary bypass grafting with or without cardiopulmonary bypass pump
}

\author{
P Kwinecki ${ }^{*}$ T Stankowski, A Kędziora, A Pawęzowska, SS Aboul-Hassan, R Cichoń \\ From 23rd World Congress of the World Society of Cardio-Thoracic Surgeons \\ Split, Croatia. 12-15 September 2013
}

\section{Background}

The type of treatment can be chosen depending on the amount, localization and the advancement of stenosis in the coronary arteries. Aim of this study is to compare the results of surgical treatment of ischemic heart disease using the extracorporal circulation (ECC) - CABG or without the ECC - OPCAB.

\section{Methods}

In this study 616 patients were evaluated $(78 \%$ males, $22 \%$ females, Euroscore: $4.8 \pm 2.73$, age: $65 \pm 8.91$ years old). 1st group - 316 patients ( $75 \%$ males, $25 \%$ females,

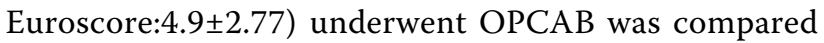
with 2nd - group who underwent CABG (300 patients, $81 \%$ males, $19 \%$ females, Euroscore: $4.7 \pm 2.69$ ) in terms of the amount revascularized vessels, amount of reoperations caused by postoperative bleeding, amount of postoperative blood loss, amount of blood products transfused and postoperative complications.

\section{Results}

Duration of OPCAB- $2 \mathrm{hrs} 28 \mathrm{~min} \pm 34.63 \mathrm{~min}, \mathrm{CABG}-$ $2 \mathrm{hrs} 54 \mathrm{~min} \pm 34.28 \mathrm{~min}(\mathrm{p}<0.001)$. Average amount of vessels which underwent revascularization in the OPCAB group was 2.3, in the control group was $2.9(\mathrm{p}=0.003)$. Average amount of postoperative drainage 18 hours after the surgery:1st group $566 \mathrm{ml}$ vs $760 \mathrm{ml}(\mathrm{p}<0.001)$. Average amount of transfused blood products:PRBC 1st group $0.7 \mathrm{U}$ vs $1.7 \mathrm{U}(\mathrm{p}<0.001)$; Platelets - 1st group $0.5 \mathrm{U}$ vs $1.2 \mathrm{U}$ ( $\mathrm{p}<0.001)$; Plasma - 1st group $0.6 \mathrm{U}$ vs $1.5 \mathrm{U}$ $(\mathrm{p}<0.001)$. Rethoractomy caused by postoperative bleeding: 1 st group $1.26 \%$ vs $3.67 \%(\mathrm{p}=0.05)$. Major Adverse

\footnotetext{
* Correspondence: pawelkwinecki@interia.pl

Heart Diseases Center MEDINET, Wroclaw, Poland
}

Cardiac and Cerebrovascular event (MACCE) in: 1stgroup $3.1 \%$ vs $3.0 \%(\mathrm{p}>0.05)$.

\section{Conclusion}

Despite the statistically significant difference of number of grafts per patient, OPCAB procedure providesreduced duration of the surgery, postoperative drainage and transfused blood products. The similar MACCE amount in both groups suggests that the OPCAB revascularization was efficient.

Published: 11 September 2013

doi:10.1186/1749-8090-8-S1-0188

Cite this article as: Kwinecki et al:: Evaluation of the results of patients who underwent coronary bypass grafting with or without

cardiopulmonary bypass pump. Journal of Cardiothoracic Surgery 20138 (Suppl 1):0188.
Submit your next manuscript to BioMed Central and take full advantage of:

- Convenient online submission

- Thorough peer review

- No space constraints or color figure charges

- Immediate publication on acceptance

- Inclusion in PubMed, CAS, Scopus and Google Scholar

- Research which is freely available for redistribution
C Biomed Central
C Biomed Central

(c) 2013 Kwinecki et al; licensee BioMed Central Ltd. This is an Open Access article distributed under the terms of the Creative Commons Attribution License (http://creativecommons.org/licenses/by/2.0), which permits unrestricted use, distribution, and reproduction in any medium, provided the original work is properly cited. 